\title{
INTERPRETASI MEDIA LUAR RUANG IKLAN ROKOK DAN POLA HIDUP SEHAT MASYARAKAT DESA SALUASSING
}

\author{
Yunalpi ${ }^{1}$, Muhammad Syaeba ${ }^{2}$, Ulya Sunani3 \\ ${ }^{1}$ Prodi Ilmu Komunikasi, Fakultas Ilmu-ilmu Sosial dan Ilmu Pemerintahan \\ Universitas Al Asyariah Mandar \\ Email: yuros@gmail.com \\ ${ }^{2}$ Prodi Ilmu Komunikasi, Fakultas Ilmu-ilmu Sosial dan Ilmu Pemerintahan \\ Universitas Al Asyariah Mandar \\ Email: syaeban@gmail.com \\ ${ }^{3}$ Prodi Ilmu Komunikasi, Fakultas Ilmu-ilmu Sosial dan Ilmu Pemerintahan \\ Universitas Al Asyariah Mandar \\ Email: ulyasunani@yahoo.co.id
}

\section{$\operatorname{ABSTR} A C T$}

This study aims to determine the public's interpretation of the outdoor media for cigarette advertising and the healthy lifestyle of the people of Sawidesing Village. The research method used is descriptive qualitative method. Data were obtained through interviews, surveys, and documentation. The results showed that the outdoor media for cigarette advertising is a very helpful message in bridging the understanding of the existence of a cigarette product, especially useful on the sales side. Meanwhile, regarding cigarettes and their healthy lifestyle, smoking is a part of life that really helps all their daily activities. Cigarettes actually become an element that makes citizens always healthy in their activities from young to old.

\section{ABSTRAK}

Penelitian ini bertujuan untuk mengetahui interpretsi masyarakat terhadap media luar ruang iklan rokok dan pola hidup sehat masyarakat Desa Saluassing. Metode penelitian yang digunakan yaitu metode kualitatif deksriptif. Data diperoleh melalui wawancara, survei, dan dokumentasi. Hasil penelitian menunjukkan bahwa media luar ruang iklan rokok merupakan pesan yang sangat membantu menjembatani pemahaman tentang tentang keberadaan sebuah poduk rokok, terutama bermanfaat pada sisi penjualan. Sementara terhadap rokok dan pola hidup sehatnya bahwa rokok merupakan bagian dari kehidupan yang sangat membantu segala aktivitas keseharian mereka. Rokok justru menjadi unsur yang membuat warga selalu sehat dalam beraktivitas sejak usia muda hingga tua.

Kata Kunci: Media Luar Ruang, Iklan Rokok, Advertising. 


\section{PENDAHULUAN}

Media luar ruang dapat diartikan sebagai segala sesuatu yang digunakan untuk memudahkan suatu pekerjaan. Teknologi yang digunakan umumnya berupa komputer, hand phone, telephone, televisi, radio, dan lain-lain. Teknologi memiliki keunggulan tersendiri pada setiap fungsinya. Misalnya media luar ruang dapat membantu memudahkan komunikasi secara luas. Media luar ruang digunakan untuk proses penghantar pesan, pertandingan olah raga, iklan rokok, kompetisi ajang pencarian bakat, reality show, sinetron, iklan, dan sebagainya.

Media luar ruang yang digunakan untuk menyiarkan iklan memiliki keunggulan dalam promosi suatu merek produk karena dapat dilihat secara luas oleh pemirsa. Iklan ialah suatu bentuk komunikasi yang digunakan untuk menyampaikan suatu informasi tentang produk, layanan, ataupun informasi lainnya.

Iklan media luar ruang pada umumnya lebih mudah mempengaruhi pemirsa karena setiap hari, melihat, bahkan setiap kios media luar ruang selalu di sela dengan iklan. Dengan begitu suatu produk yang secara terus menerus ditayangkan akan meninggalkan bekas pada ingatan pemirsa, sehingga mereka akan mulai terpengaruh dengan produk yang di iklankan.

Sebuah iklan produk akan memberikan cara yang selalu memikat orang yang melibatkannya. Suatu merek produk akan menarik perhatian orang yang memperhatikan iklan. Pemirsa yang melihat kemudahan-kemudahan yang ditayangkan sebuah iklan, pada akhirnya tertarik untuk memiliki produk yang di iklankan dengan maksud agar dapat meringankan pekerjaannya. Dan pada akhirnya mereka mulai berminat untuk memiliki produk tersebut.

Atvertising dapat di defenisikan sebagai "any paid form nonpersonsl communication about an organization, service, or idea by an identified sponsor" (setiap bentuk komunikasi non-personal mengenai suatu organisasi, produk, servis, atau ide yang dibayar oleh suatu sponsor yang di ketahuinya).

Adapun maksud dibayar pada defenisi tersebut menemukan fakta bahwa ruang dan waktu bagi suatu pesan iklan pada umumnya harus dibeli. Maksud kata 'nonpersonal' berarti suatu iklan melibatkan media massa (koran, radio, majalah, televisi) yang dapat mengirimkan pesan kepada sejumlah besar kelompok individu pada saat bersamaan. Dengan demikian sifat nonpersonal iklan berarti pada umumnya tidak tersedia kesempatan untuk mendapatakan umpan balik yang segera dari penerima pesan.

Iklan merupakan salah satu bentuk promosi yang paling dikenal dan paling banyak dibahas orang. Hal ini kemungkinan karena daya jangkauwannya yang luas. Iklan juga menjadi instrument promosi yang sangat penting khususnya bagi perusahaan yang memproduksi barang atau jasa yang ditujukan kepada masyarakat luas. 
Iklan media luar ruang pada umumnya terdiri atas iklan sponsorship, iklan layanan masyarakat, iklan spot, promo ad, dan iklan politik. Iklan media luar ruang berkembang dengan berbagai kategori disamping karena iklan media luar ruang perlu kreativitas dan menghasilkan prodok-produk iklan baru, juga karena daya beli masyarakat terhadap sebuah iklan. Media luar ruang selalu bervariasi karena tekanan ekonomi. Namun jika dibandingkan dengan media lain, iklan media luar memiliki kategorisasi yang jauh berbeda karena sifat media yang juga berbeda.

Kategori besar dari sebuah iklan media luar ruang ialah berdasarkan sifat media ini. Media iklan media luar ruang di bangun dari kekuatan visualisasi objek dan kekuatan audio. Simbol-simbol yang divisualisasi lebih menonjol bila di bandingkan dengan simbol-simbol verbal. Umumnya iklan media luar ruang menggunakan cerita-cerita pendek. Maka iklan media luar ruang berupaya keras meninggalkan kesan yang mendalam bagi pemirsa dalam waktu beberapa detik.

Suatu masyarakat terhadap sebuah iklan yang ditayangkan media luar ruang dapat dipengaruhi oleh beberapa faktor. Konsumen tidak membuat keputusan pembelian pada suatu lingkungan yang terisolasi. Konsumen berada di tengah masyarakat dan berinteraksi dengan masyarakat tempat dia berada. Dalam hal ini terdapat faktor eksternal yang diketahui memberi pengaruh pada proses pengambilan keputusan. Faktor yang paling luas dan paling abstrak mempengaruhi pembelian ialah faktor budaya yang merupakan suatu kompleksitas dari makna, nilai, norma, dan tradisi yang dipelajari dan dibagi oleh anggota suatu masyarakat.

Norma dan nilai budaya memberikan arah dan petunjuk kepada anggota masyarakat dalam berbagai aspek kehidupan, termasuk juga perilaku komsumsi mereka. Faktor budaya merupakan penentu perilaku yang paling besar. Dalam hal inilah iklan selalu berkaitan dengan kajian wacana, dimana wacana diproduksi melalui iklan untuk mempengaruhi budaya. Hamdan (2019) menjelaskan bahwa dalam setiap produksi barang, sesungguhnya secara tersembunyi mengikut produksi wacana dan produksi budaya.

Di Desa Saluassing, media luar ruang iklan rokok terpasang di berbagai sudut Desa, terutama berada di depan kios atau toko penjual dalam bentuk banner dan baliho. Konten iklan sangat beragam tergantung jenis produk atau merek yang di tawarkan. Keberadaannya merupakan bagian integaral dari produk yang di jual dalam kios atau toko, yakni rokok.

Rokok juga merupakan bagian tak terpisahkan dari kehidupan masarakat Desa Saluassing. Di sana, bisa dikatakan kebanyakan laki-laki adalah perokok. Begitupun dengan perempuan, yang ada beberapa di antaranya merokok. Hal tersebut merupakan bagian dari aktivitas kehidupan mereka.

Kebanyakan masarakat Desa Saluassing tidak bisa kerja atau cari uang jika tidak ada rokok. Bahkan diumur 14 tahun sudah ada yang merokok, di mana jika ada anak di bawah umur ini mau merokok, dia akan sembunyi atau mencari tempat yang aman untuk menghisap rokok. Dalam pola kehidupan masarakat Desa 
Saluassing, rokok selalu diidentikkan dengan penyakit, pun kerap mendapat stigma sebagai orang yang kebal penyakit, karena tidak sedikit orang merokok tetap sehat sehingga usia lanjut pun masih merokok.

Contoh paling jelas dari kasus ini adalah salah satu warga Desa Saluassing yang berumur hampir 100 Tahun masih sehat dan masih mengisap rokok. Mereka yang di kategorikan orang tua kebanyakan masih merokok. Hal tersebut sebenarnya sudah cukup untuk membantah stigma perokok cepat mati atau rokok adalah penyebab utama penyakit berbahaya dan kematian.

Pola aktivitas hidup sehat masarakat Desa Saluassing tergantung pada seseorang yang merokok dan tidak merokok, karena ada orang yang merokok lalu berhenti merokok pasti sakit, atau merasakan kelainan karena sudah terbiasa merokok lalu tiba-tiba berhenti. Begitu pun sebaliknya jika orang tersebut tidak terbiasa merokok lalu merokok pasti akan terasa berbeda,catau mengakibatkan sakit kepala.

Hal tersebutlah yang menarik bagi peneliti untuk mengetahui bagaimana interpretasi masyarakat tentang banyaknya media luar ruang iklan rokok yang berupa banner dan baliho yang terpasang di depan toko atau kios dengan pola kehidupan masyarakat Desa Saluassing terkait rokok.

\section{METODE PENELITIAN}

Penelitian ini merupakan penelitian kualitatif deskriktif yakni penelitian yang berupaya mengungkapkan suatu masaalah dan keadaan sebagaimana adanya. Sumber data diperoleh melalui wawancara, observasi maupun dokumentasi. Peneliti terlibat wawancara menggunakan kelompok informan dari beberapa kalangan di antaranya kios atau penjual campuran. Wawancara dilakukan dengan cara mendalam (indefth interview), wawancara dilakukan menggunakan cara bebas tetapi terarah. Selain itu digunakan pula diskusi dengan para informan.

Pengamatan langsung terutama dilakukan buat melihat secara langsung tindakan-tindakan para penjual baik yang berkaitan menggunakan penjual campuran. System dokumentasi dilakukan dengan pencatatan (field note), perekaman. Penjaringan data sekunder dilakukan melalui aktivitas penelahan dokumen-dokumen formal dan nonforman masyarakat. Proses analisis data dilakukan melalui reduksi data, penyajian data dan konklusi atau verifikasi.

\section{HASIL PENELITIAN}

Dalam kehidupan keseharian masyarakat Desa Saluassing, baliho iklan rokok sangat bermanfaat. Ketika sebuah kios yang ada di Desa Saluassing memasang baliho iklan rokok di depan kios, baliho itu sangat berguna bagi penjual maupun pembeli. Artinya bahwa terjadi suatu hubungan saling menguntungkan antara penjual dan pembeli. Sebagai contoh, baliho yang terpasang di salah satu 
Dusun yaitu baliho rokok Surya. Rokok ini menjadi rokok yang banyak berminat dan tertarik untuk menggunakannya.

Dengan kata lain bahwa baliho sebagai media ruang luar, menjadi media yang cukup penting dan berpengaruh terhadap khalayak perokok pada umumnya. Melalui media ini, pesan yang disampaikan cukup efektif mempengaruhi pikiran khalayak sehingga khlayak dapat mengikuti apa keinginan pesan yang terkandung dalam iklan.

Sehubungan dengan iklan rokok Surya, peneliti mewawancarai seorang prokok paruh baya yang biasa dipanggil Ambek. Sebenarnya, rokok yang dihisap Ambek ini tidak menentu. Kadang jika anaknya mengirimkan uang dari Malaysia rokok yang dibeli adalah rokok Surya Gudang Garam. Tetapi juga saat Ambek tidak punya uang pembeli rokok, dia menggulung rokok dengan kulit jagung yang sudah kering, atau oleh masyarkat Mamasa sering disebut rokok bakak. Ambek Sese sejak berumur 7 tahun telah mencoba menghisap rokok, menjadi perokok aktif, sehingga sampai sekarang masih kuat (sehat), menurutnya.

Pengamatan dan interpretasi masyarakat tentang media luar ruang iklan rokok sebagian cukup positif, menganggap bahwa media luar itu sangatlah bagus ketika ditempatkan pada kios-kios yang mungkin pengunjungnya banyak. Dengan begitu, kios-kios lain juga bisa meniru hal serupa agar dapat menambah jumlah pengunjung atau pelanggannya.

Wawancara penulis dengan beberapa warga Saluassing mengenai rokok dan pola hidup sehat, mereka mengatakan bahwa soal hidup sehat sebenarnya, semua manusia punya cara dan prilaku untuk menjaga pola hidup sehatnya. Dan selain itu, tidak kalah pentingnya adalah bagaimana cara mensupport pola sehat masingmasing kelompok seperti di Desa Saluassing.

Masyarakat Desa Saluassing, dalam hubungannya dengan prilaku merokok, di satu sisi dapat dikategorikan masih minim dalam menjaga pola sehat mereka. Contohnya bahwa cara pandang masyarakat Desa Saluassing terhadap rokok sungguh kontra produktif. Masyarakat menganggap bahwa rokok itu layaknya makanan pokok keseharian mereka yang tak dapat dipisahkan. Bahkan rokok menjadi lebih penting dari makanan. Menurut tanggapan dari Bapak Tanji mengatakan bahwa saya masyarakat yang tergolong dalam masyarakat tidak mampu. Jika saya bekerja lalu tidak ada rokok, pekerjaan itu tidak akan selesaiselasai. meskipun terdapat berapa macam makanan yang dapat memancing selera untuk makan, saya tidak akan makan kalau tidak ada rokok. Begitu pentingnya rokok dalam kehidupan saya.

Pandangan tersebut tentunya berlawanan dengan pesan kesehatan yang tertera pada setiap bungkus rokok. Pemerintah mewajibkan pada setiap produk rokok untuk mmencantumkan peringatan bahaya merokok. Namun sebaliknya warga Saluassing justru merasa kesehatannya terganggu jika dijauhkan dari rokok. 
Rokok adalah lintingan atau gulungan tembakau yang di dibungkus menggunakan kertas, daun, atau kulit jagung, sebesar kelingking dengan panjang 8-10 cm, umumnya dihisap seseorang setelah ujungnya dibakar. Rokok merupakan pabrik bahan kimia berbahaya. Hanya menggunakan, membakar dan menghisap sebatang rokok saja, dapat diproduksi lebih 4000 jenis bahan kimia. Dari jumalh itu, 400 di antaranya beracun dan 40 antaranya sanggup berakumulasi pada tubuh dan bisa menyebabkan kanker. Pola hidup sehat merupakan upaya seseorang buat menjaga tubuhnya agar permanen sehat. Pola hidup sehat bisa dilakukan menggunakan cara mengonsumsi kuliner bergizi, olahraga secara rutin, dan istirahat yang cukup

Kebanyakan dari kita menganggap bahwa pola hidup sehat adalah pola hayati yang sulit buat di jalani. Namun sebenarnya, ada cara yang gampang di lakukan buat menjaga diri kita tetap sehat. Tujuan atau manfaat dari pola hidup sehat tentunya untuk menjaga kesehatan tubuh supaya tidak mudah sakit. Tapi menerapkan pola hidup sehat memiliki beberapa tujuan juga, misalnya; kesehatan jasmani dan rohani dapat selalu terjaga dan supaya memiliki kesehatan mental yang stabil sehingga tidak mudah depresi atau pun stress.

Media luar ruang adalah sebuah iklan yang dipasang di luar ruang, karna di dalamnya terdapat bagian-bagian yang bisa dinikmati warga Desa Saluassing khususnya iklan rokok. Karena media luar ruang iklan rokok ini adalah penghatarkan pesan pada pembeli. Media luar ruang merupakan media yang dipasang di luar ruangan yang memiliki ciri khas dan model masing-masing sabagaimana masyarakat di Desa Saluassing ada juga memasang media luar ruang bukan dengan tempatnya.

Media dalam aktivitas bidang pelayanan publik merupakan komunikasi yang dilaksankan sang intitusi yang berperan memberikan pelayanan publik yang berbau himbauan kepada pembaca atau masyarakat yg memuat pemberitaan, membujuk, dan mempengaruhi segalah sesuatu mengenai pelayanan publik dengan menentukan perilaku rakyat akan pola hidup yang dihasilakan buat pembaca melalui sosialisasi dalam bentuk iklan.

Pada hakikatnya media adalah suatu bentuk komunikasi pemasaran. Adapun yang dimaksud komunikasi pemasaran adalah aktifitas pemasaran yang berusaha mengembangkan informasi, mempengaruhi, membujuk, dan mengingatkan pasar sasaran perusahaan dan produknya supaya bersedia menerima, membeli loyal dalam produk yang ditawarkan perusahaan yang bersangkutan.

Sebagai sebuah pesan, media luar ruang beragam model dan rona sesuai merek dan kesukaan. Hal ini sesuai dengan pemaknaan pesan dalam komunikasi, bahwa sebuah makna pesan terkait bagai mana proses pemasangan media luar ruang tersebut. Dalam proses pemasangan media luar ruang, pada komunikasi masyarakat tentang iklan rokok bahwa berdasarkan proses pemasangan media luar ruang sangatlah gampang dan tidak memerlukan orang atau tenaga yang banyak. Media luar ruang ini bisa dikerjakan atau dipasang oleh satu orang saja. 
Dari pembahasan mengenai interpretasi warga Desa Saluassing terhadap media luar ruang iklan rokok, berdasarkan hasil observasi bahwa dari interpretasi warga mengenai media luar ruang belum terlalu dipahami menggunakan dengan baik apa sebenarnya media tersebut. Bagi masyarakat Desa Saluassing kebanyakan iklan itu tidak dipergunakan di tempatnya. Penulis biasa temui iklan dipasang di gubuk-gubuk dan juga dijadikan atap sangkar ternak mereka. Selain media luar ruang iklan rokok, ada juga media luar ruang lain yang di pakai bukan pada tempatnya.

Menurut tanggapan pak Juni bahwa ia telah bertahun-tahun menjalankan bisnis berjualan dan baru sejak tahun 2017 memasang banner atau baliho iklan rokok. Banyak sekali manfaat bagi dia sebagai pemilik kios. Masyarakat Desa Saluassing tidak tahu bahwa media luar ruang menjadi pengingat sangat penting buat produk yang telah Mapan.

Dengan demikian rakyat Desa Saluassing tidak sadar akan adanya media media yang bisa memberikan efek positif bagi warga. menurut pernyataan salah seseorang pemilik kios yaitu Bapak Ahmad, secara pribadi mengungkapkan bahwa sebenarnya berdasarkan adanya media luar ruang ini, sangat berguna dan banyak sekali manfaatnya. Tetapi sayangnya penjual lain yang lain tidak memanfaatkan media luar ruang ini dengan tempatnya.

Demikian juga selama penulis melakukan observasi, memang banyak sekali masyarakat yang mempergunakan media luar ruang dengan baik contohnya bahwa seharusnya media luar ruang itu di pasang di tempatnya. Contohnya media luar ruang iklan rokok, seharusnya dipasang di kios atau tempat penjualan Rokok. Dari hasil wawancara dengan Hartoni mengatakan baliho iklan rokok sangat bermanfaat bagi masyarakat terlebih khusus pada penjual atau pemilik kios. Karena menurutnya media ini sangat menarik.

Semua wawancara dengan warga Desa Saluassing mengenai baliho iklan rokok menanggapi bahwa baliho iklan rokok itu pada umumnya sangat bermanfaat bagi masyarakat khusus para pemilik kios yang ada di Desa Saluassing. Menurut penulis memang betul bahwa baliho iklan rokok ini sangat bermanfaat bagi masyarakat. Lalu dari hasil obsevasi penulis bahwa banner kebanyakan memasang di gubuk kebun mereka, dan juga masyarakat memasangnya di kebun sayur mereka yang ada di dekat rumahnya. Sehingga ada manfaat sampingan dari baliho iklan rokok ini bagi masyarakat, tetapi menempatkan baliho rokok ini di tempat tidak yang sebenarnya.

Menurut Ambe' Sese mengatakan bahwa media luar ruang iklan rokok ini sangat baik dan bermanfaat. Orang yang buta huruf saja bisa memanfaatkan media luar dengan baik, apalagi orang yang tidak buta huruf. Sepanjang banner atau baliho yang baik dipandang oleh kalangan masyarakat itu sangat bermanfaat bagi masyarakat. Mengenai pandangan dari Ambe' Sese memang betul bahwa media luar ruang ini sangat bermanfaat bagi masyarakat jika dimanfaatkan dengan baik. 
Namun ada juga yang berpendapat lain, yang mengatakan bahwa rokok adalah obat bagi saya, dan ada juga mengatakan bahwa rokok itu penghantar rejeki. Masyarakat Desa Saluassing itu pekerjaan sehari-harinya umumnya bertani, dan semuanya merokok. Sebagian masyarakat Desa Saluassing mengatakan pola hidup sehatnya tergantung pada rokok.

Menurut dari salah satu informan bahwa rokok bagi saya itu sangat membantu atau menjhadi penyemangat. Karena di dalam melakukan pekerjaan sehari-hari tanpa rokok aktivitas tidak berjalan. Kemudian dengan pola hidup sehat tanpa rokok, hidup saya tidak berguna apalagi dalam melakukan aktivitas keseharian. Hal serupa dikatakan oleh Indo' Pepe bahwa pola hidup sehat saya bergantung pada rokok, tanpa rokok saya tidak sehat.

\section{KESIMPULAN}

Berdasarkan hasil penelitian, penulis menyimpulkan bahwa interpretasi masyarakat Desa Saluassing terhadap media luar ruang iklan rokok merupakan pesan yang sangat membantu menjembatani pemahaman tentang tentang keberadaan sebuah poduk rokok, terutama bermanfaat pada sisi penjualan. Sementara terhadap rokok dan pola hidup sehatnya bahwa rokok merupakan bagian dari kehidupan yang sangat membantu segala aktivitas keseharian mereka. Rokok justru menjadi unsur yang membuat warga selalu sehat dalam beraktivitas sejak usia muda hingga tua. Dengan demikian, iklan rokok sesungguhnya merupakan sesungguhnya hanya merupakan pendukung persepsi, sebab tanpa iklan pun warga Desa Saluassing telah menjadikan rokok sebagai kebutuhan primer dalam hidup sehari-hari.

\section{SARAN}

Penelitian ini masih memerlukan kajian yang lebih mendalam terutama seberapa jauh warga dapat memahami pesan yang terkandung dalam media luar ruang. Hal lain adalah, seberapa pentingkah media iklan rokok pada masyarakat yang memiliki tradisi merokok yang tinggi. Sebab dalam kasus Desa Saluassing, lembar baliho dan banner justru digunakan sebagai atap atau dinding gubuk kebun mereka.

\section{DAFTAR PUSTAKA}

Abdurachman,O. (2001), Dasar-Dasar publik relation, Bandung; Citra Aditya Bakti.

Ardianto,E, \& Erdinaya, I,,K. (2004), Komunikasi Massa: Suatu pengantar.

Edward, Maibach. 1995. Desikning Healih Messages, Approaches From Communcation Theory and Public Healih Practice, Sage Publications, Intrnational and Profesional Publiser Thousand Oaks London. 
Elena, Maria and Lawrence, Kincaid, 2002. Communication for Social Change: An Integrated Model For Measuring the Process and its Outcomes, Rckefeller Foundation.

Ealyne Clif. 2001. Information, Education and Commucation, WHO, New York.

Gema Pariwara. (2011). Prinsip-Prinsip dasar iklan. Diakses pada 2020, 24 Januari, dari; http://gemaparawira.blogspot.com/2011/04/prinsip-prinsip-Dasar-iklan.html

Hamdan, H. Wacana Dalam Perspektif Norman Fairclough. Jurnal Komodifikasi, Volume 7(1).

Himawanto, F. (2004). Pada hubungan faktor-fakor yang memintrepretasii dampak layanan iklan anti rokok terhadap kogisi dan intense remja: studi kasus ilan layanan masyarakat anti rokok Philip Morris dan Japan tobacco International di MTV. Jakarta: Universitas Indonesia.

Jensen, Klaus B. 1991. Reception Analysis: Mass Communication as Social Production of Meaning, dalam Jensen. Klaus B and Jankowski, Neholas (ed). A Handbook of Qualitative Methodologies for mass Communication Research, New York, Routhledge.

Kotler, Philip \& Andreasen. 2003. Stralegic Marketing for Non fropil Organizations, Prentice Hail.

Karliah, S., Soemirat, B., \& Komala, L., (1999), Komunikasi Massa. Jakarta: Universitas Terbuka. 